\title{
Antiviral resistance in HCV strains isolated from Romanian patients with limited treatment options for chronic HCV infection
}

\author{
Anca Streinu-Cercel ${ }^{1,2^{*}}$, Oana Săndulescu ${ }^{1,2}$, Daniela Manolache², Dragoş Florea ${ }^{2}$, Dan Oțelea², \\ Adrian Streinu-Cercel ${ }^{1,2}$ \\ From The 10th Edition of the Scientific Days of the National Institute for Infectious Diseases "Prof Dr Matei \\ Bals" \\ Bucharest, Romania. 15-17 October 2014
}

\section{Background}

With the advent of direct-acting antivirals, the rate of sustained virologic response (SVR) after treatment for chronic $\mathrm{HCV}$ infection has dramatically increased [1]. However, recent data show that there is cause for concern regarding the potential emergence of viral resistance [2].

\section{Methods}

We performed a study to assess the antiviral resistance profile in a series of patients with limited treatment options for chronic HCV infection.

\section{Results}

We assessed data from 12 patients (gender ratio 1:1), of which 10 had HCV monoinfection and 2 had HCV+HIV coinfection. The mean age was $43.8 \pm 16.5$ years (range 19-71 years). Eleven patients were infected with HCV genotype $1 \mathrm{~b}$, and one patient had been coinfected with genotype $2 \mathrm{a} / 2 \mathrm{c}$ but had spontaneously cleared $2 \mathrm{a}$ infection and was now monoinfected with HCV 2c.

Only one patient had IL28-B genotype CC, 4 patients CT and 5 patients TT (in two cases data on IL28-B were not available). Seven of the patients had received prior anti-HCV therapy: 2 with peg-interferon+ribavirin, 2 with faldaprevir-based regimens and 3 with telaprevir-based regimens. Of them, 3 had been non-responders and 4 had been relapsers.

The mean plasma HCV-RNA was $6.1 \pm 0.7 \log _{10}$ IU/ $\mathrm{mL}$. Patients were distributed over the whole range of fibrosis values on FibroMax, with a slight predominance of advanced fibrosis: F3 (2 patients) and F4 (3 patients).

Resistance to boceprevir or simeprevir was identified in $3 / 12$ cases (fold-change range: $4-24$ ) and $2 / 12$ cases (fold-change range: $32-38$ ), respectively, although none of the patients had received prior therapy with these antivirals.

Resistance to telaprevir was identified in $3 / 12$ cases (surprisingly, none of the cases with telaprevir therapy). Possible resistance was identified in another 6 cases (including cases treated with telaprevir and faldaprevir). The overall fold-change range was 1.8-22.4.

Resistance to faldaprevir was identified in $3 / 12$ cases (surprisingly, none of the cases with faldaprevir therapy), with a fold-change range of 1.2-360.0.

\section{Conclusion}

Cross-resistance to $\mathrm{HCV}$ protease inhibitors (PI) remains a cause for concern, particularly in patients with history of treatment with HCV PI-based regimens.

\section{Acknowledgment \\ This paper is partially supported by the Sectoral Operational Programme Human Resources Development (SOP HRD), financed from the European Social Fund and by the Romanian Government under the contract numbers POSDRU/159/1.5/S/137390.}

\section{Authors' details}

${ }^{1}$ Carol Davila University of Medicine and Pharmacy, Bucharest, Romania. ${ }^{2}$ National Institute for Infectious Diseases "Prof. Dr. Matei Balş", Bucharest, Romania.

\footnotetext{
* Correspondence: anca_sc@yahoo.com

${ }^{1}$ Carol Davila University of Medicine and Pharmacy, Bucharest, Romania

Full list of author information is available at the end of the article
} 
Published: 15 October 2014

\section{References}

1. Streinu-Cercel A: Hepatitis $C$ in the interferon-free era. GERMS 2013, 3:114.

2. Poveda E, Wyles DL, Mena A, Pedreira JD, Castro-Iglesias A, Cachay E:

Update on hepatitis $C$ virus resistance to direct-acting antiviral agents. Antiviral Res 2014, 108C:181-191.

doi:10.1186/1471-2334-14-S7-P8

Cite this article as: Streinu-Cercel et al: Antiviral resistance in HCV

strains isolated from Romanian patients with limited treatment options

for chronic HCV infection. BMC Infectious Diseases 2014 14(Suppl 7):P8.

Submit your next manuscript to BioMed Central and take full advantage of:

- Convenient online submission

- Thorough peer review

- No space constraints or color figure charges

- Immediate publication on acceptance

- Inclusion in PubMed, CAS, Scopus and Google Scholar

- Research which is freely available for redistribution

Submit your manuscript at www.biomedcentral.com/submit
Ciomed Central 